Morris, E. J. (1955). J. gen. Microbiol. 13, 456-460

\title{
A Selective Medium for Bacillus anthracis
}

\author{
By E. J. MORRIS \\ Microbiological Research Department, Ministry of Supply, Porton, Wiltshire
}

SUMMARY: A medium containing propamidine is described which has high selective activity for the species Bacillus anthracis. The spore form of the organism is essential as inoculum for the medium.

The isolation of Bacillus anthracis from material heavily contaminated by other organisms of the same genus can be difficult, particularly when small numbers of $\boldsymbol{B}$. anthracis are present, or when quantitative examination is required. Pearce \& Powell (1951) did much to simplify this problem by devising a medium containing lysozyme and haemin, but considerable numbers of other sporing organisms found in soil were not suppressed. The antibacterial activity of diamidines has been studied by many workers (e.g. Bernheim, 1943; Elson, 1945; Wein, Harrison \& Freeman, 1948). Lacey (1954) used 4: : 4-diamidino-phenylamine as a selective agent for Haemophilus pertussis. In the present study it was found that 4:4-diamidino-diphenoxypropane (propamidine) allowed the germination of Bacillus anthracis spores with subsequent growth and multiplication of cells while it inhibited the growth of practically all other organisms tested. The medium finally devised is more selective for $\boldsymbol{B}$. anthracis than any other so far reported.

\section{METHODS}

Media. The basal medium was a peptone agar containing Evans peptone $2 \%$ $(\mathrm{w} / \mathrm{v}), \mathrm{NaCl} 0.5 \%(\mathrm{w} / \mathrm{v})$ and agar $2 \%$ (Kobé no. 1; Stafford Allen and Sons Ltd.) adjusted to $\mathrm{pH} 7 \cdot 6$ and sterilized at $120^{\circ}$ for $20 \mathrm{~min}$. For control purposes this medium was used with and without the addition of $1 \%(\mathrm{v} / \mathrm{v})$ packed red blood cells (several different species were used, see below). The test medium contained $1 \%$ packed red cells, $0.01 \%$ (w/v) propamidine isethionate (May and Baker Ltd.) and 20 units polymyxin B ('Aerosporin' Burroughs Wellcome and Co.) $/ \mathrm{ml}$. The additions were made to the melted agar cooled to $50^{\circ}$ and poured into Petri dishes in $20 \mathrm{ml}$. amounts. The agar plates were dried for $2 \mathrm{hr}$. at $37^{\circ}$ to remove surface moisture and could be stored at $4^{\circ}$ for at least 3 weeks without loss in selective properties.

Human, horse, sheep, or rabbit blood cells could be used. Whole blood was as good as packed cells, but concentrations above $2 \%(\mathrm{v} / \mathrm{v})$ allowed the growth of many more contaminants present in the inoculum.

Changes in the $\mathrm{pH}$ value of the medium greatly affected the inhibitory activity of the propamidine. The higher activity at $\mathrm{pH} 8.0$ restricted the growth of Bacillus anthracis, while at $\mathrm{pH} \mathrm{7.0}$ the medium had a diminished selective action. 
Growth tests. The Miles \& Misra (1938) technique was used to inoculate the control and test media. Broth cultures, spore suspensions and soil extracts were tested. The latter were prepared by extracting various samples of soil to which Bacillus anthracis had been added with water $(1 \mathrm{~g}$. soil $/ 20 \mathrm{ml}$. water) and heating at $60^{\circ}$ for $30 \mathrm{~min}$. before use. Portions of the heated soil extract were also filtered through Millipore membranes (Millipore Filter Corporation of America) which after filtration were placed with deposit upwards on the agar media.

Air from animal rooms and laboratories was sampled directly upon the control and test agar plates with the slit sampler of Bourdillon, Lidwell \& Thomas (1941).

In all tests incubation was at $37^{\circ}$ for $18 \mathrm{hr}$.

\section{RESULTS}

Growth of pure cultures. Seven species of spore-forming aerobes (in all 40 strains) and 7 species of non-spore-forming aerobes ( 21 strains) were tested. The 15 strains of Bacillus anthracis examined all gave quantitatively similar counts on the propamidine and control agar. Colonies were slightly smaller $(1.8 \mathrm{~mm}$.) on the test medium than on the control agar $(2.0 \mathrm{~mm}$.), and the 'medusa head' effect more marked. 'There was no difference between the morphology of organisms from test and control media.

The other spore-forming aerobes examined were completely inhibited on the propamidine medium, with the exception of some strains of Bacillus cereus. Most strains of this species, however, were readily differentiated from $\boldsymbol{B}$. anthracis by their production of marked haemolysis in the medium and by their larger colony size (3-4 mm.).

The other Gram-positive and Gram-negative species tested were completely inhibited with the exception of Proteus vulgaris. This organism was prevented from swarming, and the growth of one strain was markedly decreased. Results are summarized in Table $\mathbf{1 .}$

Tests with soil extracts. Many samples of soil from downland and farmyards in Wiltshire were examined. There was great variation in number and type of organisms from one sample to another, and a detailed description of results would be of little value for the present purpose. Growth of the undiluted soil extract $(\mathbf{0 . 2} \mathrm{ml}$./plate) on the control medium was generally confluent, but the highest number of colonies, other than Bacillus anthracis, encountered on the propamidine agar was $35 /$ plate. The majority of these colonies were immediately differentiated from those of $\boldsymbol{B}$. anthracis by their colonial appearance, but some non-haemolytic strains of $B$. cereus required incubation for at least $24 \mathrm{hr}$. before their colonies could be differentiated with certainty. A small number of $B$. mycoides (B. cereus var. mycoides) strains were grown but they gave nearly invisible colonies on the propamidine medium.

Tests with Millipore filters. When $5 \mathrm{ml}$. amounts of soil extracts were filtered through Millipore pads of $6 \mathrm{~cm}$. diameter, and the deposit on the pads cultivated as previously described, there was occasionally an overgrowth of 
Bacillus anthracis by $B$. cereus. B. anthracis was isolated, however, when 50 spores were added to $1 \mathrm{~g}$. soil and 1-3 ml. amounts of the extract were passed through similar Millipore filters. The immediate identification of B. anthracis colonies which developed on the filter pads was difficult since they were smaller $(1.5 \mathrm{~mm}$.) and had a smoother appearance than when grown directly on the agar surface.

Table 1. Growth tests of various organisms on the propamidine medium

\begin{tabular}{|c|c|c|}
\hline Organism & & $\begin{array}{c}\text { Percentage of } \\
\text { count }\end{array}$ \\
\hline Bacillus anthracis & $\begin{array}{c}\text { NCTC 5444, 8234, } \\
2620,4991,1712 \\
1711,1328,109\end{array}$ & 100 \\
\hline B. anthracis & (7) & 100 \\
\hline B. cereus & NCTC 8035 & 100 \\
\hline B. cereus & (6) & Nil-100 \\
\hline B. subtilis & NCTC 3610 & Nil \\
\hline B. subtilis & (6) & Nil \\
\hline B. 'mycoides' & (4) & Nil \\
\hline B. licheniformis & (3) & Nil \\
\hline B. megaterium & (2) & Nil \\
\hline B. pumilus & (2) & Nil \\
\hline Proteus vulgaris & (3) & $30-100$ \\
\hline Escherichia coli & (4) & $\mathrm{Nil}$ \\
\hline Aerobacter aerogenes & (2) & Nil \\
\hline Alcaligenes faecalis & (6) & Nil \\
\hline Streptococcus faecalis & (1) & $\mathrm{Nil}$ \\
\hline Micrococcus tetragenus & (3) & Nil \\
\hline Staphylococcus aureus & (2) & Nil \\
\hline
\end{tabular}

Figures in parentheses refer to the number of laboratory strains tested. Spore suspensions were used where applicable.

Tests with air samples. The propamidine medium inhibited $90 \%$ of the organisms which appeared on control plates. The colonies of those organisms which grew were minute and would readily have been differentiated from Bacillus anthracis had it been present in the air sampled.

Inhibition of vegetative cell inocula. It was found that while an inoculum of Bacillus anthracis spores was not inhibited on the propamidine medium, a vegetative cell inoculum from broth culture was markedly affected. This phenomenon persisted with dilution of the propamidine to the point where no selective action on other organisms occurred. The results of a typical experiment are summarized in Table 2 . Flasks of broth (basal medium without agar) and of broth $+0.005 \%(\mathrm{w} / \mathrm{v})$ propamidine were inoculated with $\boldsymbol{B}$. anthracis spores so that a measured sample from the flasks would contain $c$. 200 spores. Such samples were taken before and during germination of the spores and plated on control and propamidine agar.

It is seen from Table 2 that the vegetative organisms from Bacillus anthracis spores which had germinated in the presence of propamidine were able to grow normally on the propamidine agar, while vegetative organisms from spores which had germinated in the control broth were markedly inhibited when plated on propamidine agar. 
In similar experiments with Bacillus subtilis and B. cereus (Table 3) samples from the germination broths were also heated at $60^{\circ}$ for $30 \mathrm{~min}$. to establish whether germination of the spores was affected by propamidine. The results in

Table 2. Growth from Bacillus anthracis (M36) spores germinated in peptone broth or in propamidine broth

$\begin{array}{lccc}\text { peptone broth or in propamidine broth } \\ \text { Counts of broth } \\ \text { Germination medium } & \begin{array}{c}\text { Period of } \\ \text { incubation } \\ \text { samples plated on }\end{array} & \begin{array}{c}\text { Propamidine } \\ \text { (hr.) }\end{array} & \begin{array}{c}\text { agar } \\ \text { Control }\end{array} \\ \text { Peptone broth } & 0 & 195 & 210 \\ & 1 & 75 & 195 \\ \text { Peptone broth }+0.005 \%(w / v) & 2 & 48 & 213 \\ \text { propamidine } & 4 & 24 & 513 \\ & 0 & 201 & 207 \\ & 1 & 225 & 207 \\ & 2 & 222 & 216 \\ & 4 & 441 & 458\end{array}$

Table 3. Growth of Bacillus cereus and B. subtilis spores germinated in peptone broth or in propamidine broth, and then plated on control agar or propamidine agar

\begin{tabular}{|c|c|c|c|c|c|}
\hline \multirow[b]{2}{*}{ Organism } & \multirow[b]{2}{*}{ Germination medium } & \multirow[b]{2}{*}{$\begin{array}{l}\text { Period of } \\
\text { incubation } \\
\text { (hr.) }\end{array}$} & \multicolumn{2}{|c|}{$\begin{array}{l}\text { Counts of broth } \\
\text { samples plated on }\end{array}$} & \multirow{2}{*}{$\begin{array}{l}\text { Counts of heated broth } \\
\text { samples* plated on: } \\
\text { Control agar }\end{array}$} \\
\hline & & & $\begin{array}{l}\text { Propamidine } \\
\text { agar }\end{array}$ & $\begin{array}{l}\text { Control } \\
\text { agar }\end{array}$ & \\
\hline $\begin{array}{l}\text { B. cereus } \\
\text { NCTC } 8035\end{array}$ & Peptone broth & $\begin{array}{l}0 \\
1 \\
2 \\
4\end{array}$ & $\begin{array}{c}168 \\
165 \\
320 \\
\text { TNTC }\end{array}$ & $\begin{array}{c}175 \\
153 \\
312 \\
\text { TNTC }\end{array}$ & $\begin{array}{r}151 \\
0 \\
0 \\
0\end{array}$ \\
\hline & $\begin{array}{c}\text { Peptone broth }+ \\
0.005 \%(w / v) \\
\text { propamidine }\end{array}$ & $\begin{array}{l}0 \\
1 \\
2 \\
4\end{array}$ & $\begin{array}{c}151 \\
185 \\
364 \\
\text { TNTC }\end{array}$ & $\begin{array}{c}178 \\
163 \\
381 \\
\text { TNTC }\end{array}$ & $\begin{array}{r}147 \\
0 \\
0 \\
0\end{array}$ \\
\hline $\begin{array}{l}\text { B. subtilis } \\
\text { NCTC } 3610\end{array}$ & Peptone broth & $\begin{array}{l}0 \\
1 \\
2 \\
4\end{array}$ & $\begin{array}{l}0 \\
0 \\
0 \\
0\end{array}$ & $\begin{array}{r}240 \\
168 \\
149 \\
2400\end{array}$ & $\begin{array}{r}216 \\
0 \\
0 \\
0\end{array}$ \\
\hline & $\begin{array}{c}\text { Peptone broth }+ \\
0 \cdot 005 \%(w / v) \\
\text { propamidine }\end{array}$ & $\begin{array}{l}0 \\
1 \\
2 \\
4\end{array}$ & $\begin{array}{l}0 \\
0 \\
0 \\
0\end{array}$ & $\begin{array}{r}253 \\
191 \\
95 \\
41\end{array}$ & $\begin{array}{r}241 \\
0 \\
0 \\
0\end{array}$ \\
\hline
\end{tabular}

* Held at $60^{\circ}$ for $30 \mathrm{~min}$. before plating; TNTC, too numerous to count.

Table 3 show that although germination of spores of both species was normal in the presence of propamidine, $\boldsymbol{B}$. subtilis spores were unable to acquire resistance to this substance. B. cereus, however, was naturally resistant to propamidine and vegetative organisms from spores which had germinated in control broth developed normally on the propamidine medium. 


\section{DISCUSSION}

The induction of resistance to the antibacterial action of propamidine in Bacillus anthracis has been shown to be a characteristic of the metabolic activity of the spore germinating in the presence of this substance. Vegetative organisms grown in the absence of propamidine fail to develop when placed in its presence. In the usual attempts to isolate $\boldsymbol{B}$. anthracis from contaminated material such as soil, the spore form is always encountered. Inhibition by the propamidine medium of the vegetative form of $\boldsymbol{B}$. anthracis, therefore, is not a serious disadvantage. The vegetative forms of other species, with the exception of $\boldsymbol{B}$. cereus, appear unable to acquire resistance to propamidine when the spores germinate in the presence of a high concentration of propamidine.

Thanks are due to Dr D. W. Henderson and Surg.-Cmdr. H. M. Darlow for their active interest and advice, also to C. M. R. Pitman for technical assistance.

\section{REFERENCES}

Bernheim, F. (1943). The effect of propamidine on bacterial metabolism. Science, 98, 223.

Bourdillon, R. B., Lidwell, O. M. \& Thomas, J. C. (1941). A slit sampler for collecting and counting airborne bacteria. J. Hyg., Camb. 41, 197.

Elson, W. O. (1945). The antibacterial and fungistatic properties of propamidine. J. infect. Dis. 76, 193.

LACEy, B. W. (1954). A new selective medium for Haemophilus pertussis, containing a diamidine, sodium fluoride and penicillin. J. Hyg., Camb. 52, 273.

Miles, A. A. \& Misra, S. S. (1938). The estimation of the bactericidal power of the blood. J. Hyg., Camb. 38, 732.

Pearce, T. W. \& Poweld, E. O. (1951). A selective medium for Bacillus anthracis. J. gen. Microbiol. 5, 387.

Wein, R., Harrison, J. \& Freeman, W. A. (1948). Diamidines as antibacterial compounds. Brit. J. Pharmacol. 3, 211.

(Received 23 May 1955) 